\title{
Financial Cooperatives as Drivers for Sustainable Development in the Knowledge Economy
}

\author{
Jonas Čepinskis ${ }^{1}$, Vytautas Žirgutis ${ }^{1}$, Sandra Žirgutienè ${ }^{2}$ \\ ${ }^{I}$ Department of Economics and Management, Vytautas Magnus University \\ ${ }^{2}$ JSC Center of Financial Management Solutions \\ cross $^{\text {ref }}$ http://dx.doi.org/10.5755/j01.erem.66.4.5497
}

(Received in October, 2013; accepted in December, 2013)

\begin{abstract}
Sustainable development in the knowledge economy faces new challenges. Sustainable development has its stakeholders and drivers; some of them are more important than the others. Financial cooperatives do not seem a substantial stakeholder of sustainable development, but only at the first sight. This paper deals with the evaluation of financial cooperatives as drivers for sustainable development in the knowledge economy through community empowerment. Cooperative banks are stakeholder-value institutions, when the traditional commercial institutions are referred to as shareholder-value ones. Members of cooperatives are their stakeholders at different levels. Small financial cooperatives, like credit unions exist to attain the economic and social goals of their members, and not maximizing profit and shareholder wealth. This enables credit unions to empower communities to pursue specific interests of their local communities. The analysis of statistical data in order to establish whether there is a correlation between the level of prevalence of credit unions in different countries and the level of development of the knowledge economy and the selected sustainable development indicators is presented in this paper. The analysis indicates for an increasing positive correlation depending on credit union industry development stage.
\end{abstract}

Keywords: financial cooperatives, credit unions, community empowerment, stakeholders, sustainable development.

\section{Introduction}

Over the recent decades, sustainable development has been promoted by a number of EU policies. The key policy development was the adoption of the Europe 2020 strategy in 2010, which aimed to transform the EU into a knowledge-based, resource efficient and low-carbon economy, by reinforcing priorities of smart, sustainable and inclusive growth.

The Rio+20 conference in 2012 helped to reconsider the EU Europe 2020 strategy as an effective tool for delivering on sustainable development. Responding to the universal challenges on sustainable development, the EU strives for ensuring a Decent Life for All by 2030 (COM (2013) 92).

Earlier popular perception that sustainable development implies constraints to growth and a compromise between the growth and protection of social structures and the environment recently is being replaced by a wider recognition of potential "winwin" scenarios. If the knowledge economy can be both more prosperous and more sustainable, then the best route to global sustainable development may be through accelerated technology development, business innovation and structural change (Johnston, 2001).

The ongoing debate about the significance and the necessity of knowledge society in creating welfare economics and ensuring sustainable development provide assumptions to analyze at a glance indirect factors influencing the sustainable development of the knowledge economy. One of the most common proposals is related to the development and application of various support and grant mechanisms that would possibly foster and encourage the sustainable development of knowledge economy. 
Such mechanisms include various forms starting from the non-refundable grants to the financial engineering instruments. The authors of this paper have made the assumption that, particularly in the community level, one of the most effective economic mechanisms for fostering the sustainable development could be a traditional cooperative financial institution, which represents not the interests of shareholders (e.g. a commercial bank), but the interest of stakeholders and communities (e.g. cooperatives - cooperative banks and credit unions).

Cooperative banks have already proved their significance in financial crisis management of 20072009 , and have attracted substantial attention from the economists and researches, trying to calculate various correlations and discussing the peculiarities of corporate management implementation by cooperatives. However the smaller scale financial market players like credit unions are still somewhere outside the official researches, thou they (their members) are actually the nearest and direct community agents and stakeholders. Many credit unions exist to further community development or sustainable international development on a local level (World Council of Credit Unions). Credit unions enable the interests of communities, and such empowerment potentially may be employed for the sustainable development in the knowledge economy.

That is why the problem arises - how to evaluate the influence of financial cooperatives for community empowerment in sustainable knowledge economy? Acknowledgment of financial cooperatives as drivers for sustainable development in the knowledge economy would enable to use more methods and ways of sustainable development.

The object of this paper is the influence of financial cooperatives for sustainable development. The aim of this paper is to analyse the impact of financial cooperatives for sustainable development in the knowledge economy. The logic and the objectives of this paper are as follows:

1) to reveal the new foundation for sustainable development;

2) to analyse the significance of community networks for sustainable development and community empowerment through financial cooperatives;

3) to discuss the role of financial cooperative institutions in the economy depending on their maturity level;

4) to calculate and evaluate correlations between knowledge economy indexes and certain statistical activity indicators and level of prevalence of financial cooperatives.

Methods of research: comparative analysis of scientific literature, statistical analysis.

\section{New Foundation for Sustainable Development}

The Rio+20 conference adopted the outcome document "The Future We Want" which highlights the current issues of sustainable development. Among the other insights, the Rio+20 pays the particular importance on engaging major groups and other stakeholders into sustainable development processes, from planning to implementation (The Future We Want, 2012)

Besides others, the Rio+20 had a focus on a green economy in the context of sustainable development. The concept of green economy does not replace sustainable development; however, by getting the economy right it can be a tool for achieving sustainable development. The key point to the success of green economy is education and investments in R\&D activities. As Staniskis noted (Staniskis, 2012), "the results of FP7 project RD4SD (R\&D for sustainable development) have largely shown the state of affairs when it comes to the integration of stakeholders into the process of R\&D. Whereas, in the countries like Sweden or the Netherlands stakeholders integration has been realised for at least the last 10 years and success seems to be somewhat stagnating at a comparatively high level, other countries, for instance, in Eastern Europe, have not even started with this process. There is a virtual absence of interdisciplinary and transdisciplinary approaches in science, development and innovation."

Rio+20 states (The Future We Want, 2012) that "we acknowledges the role of civil society and the importance of enabling all members of civil society to be actively engaged in sustainable development. We recognize that improved participation of civil society depends upon, inter alia, strengthening access to information, building civil society capacity as well as an enabling environment. We recognize that information and communication technology (ICT) is facilitating the flow of information between governments and the public. In this regard, it is essential to work toward improved access to ICT, especially broad-band network and services, and bridge the digital divide, recognizing the contribution of international cooperation in this regard."

Post-2015 Sustainable Development Agenda (Post-2015 Sustainable Development Agenda) emphasizes the recommendations on framing post2015 development agendas in ways that move towards the new approach of building a multidimensional, mutually reinforcing foundation for sustainable development. This mutually reinforcing foundation requires a new way of approaching development, which can be summarized by the latter shifts. As can be seen from the Table 1, the particular importance for building a foundation for sustainable development is seen in stakeholder engagement and collaboration. Participatory processes, transparency and accountability are essential to build the necessary cooperation among communities, governments, businesses and other stakeholders. There is growing evidence that when implementing and beneficiary stakeholders are fully involved, agreed actions are more effective. For several decades researchers are keeping on investigating the value of networks as a means to change public and private sector actions to be more supportive of sustainable development. 
Table 1. New Approach To Sustainable Development (Post-2015 Sustainable Development Agenda)

\begin{tabular}{||l|l||}
\hline From & To \\
\hline Development assistance & A universal global compact \\
\hline Top decision making & Multi-stakeholder decision-making processes \\
\hline Growth models that increase inequality and risk & Growth models that decrease inequality and risk \\
\hline Shareholder value business models & Stakeholder value business models \\
\hline Meeting “easy" development targets & Tackling systemic barriers to progress \\
\hline Damage control & Investing in resilience \\
\hline Concepts and testing & Scaled up interventions \\
\hline Multiple discrete actions & Cross-scale coordination \\
\hline
\end{tabular}

There is growing evidence that when implementing and beneficiary stakeholders are fully involved, agreed actions are more effective. For several decades researchers are keeping on investigating the value of networks as a means to change public and private sector actions to be more supportive of sustainable development.

The experts of the International Institute for Sustainable Development (Creech et. al., 2001) claim, that the fundamental deficiencies in many practices of networking are related to the limited understanding about how to conceptualize, develop and follow through on the strategic intentions of a network. The way to address this deficiency is to approach networking not just to strengthen knowledge management and sharing among members, but also to actively engage the relevant decision-makers. According to the International Institute for Sustainable Development experts of which has been experimenting with developing engagement strategies since 1996, an engagement strategy can be thought of as a systematic approach to building action-oriented relationships over time.

The stages of engagement can be thought of as levels in a pyramid, where a broad base of support is required to support a small number of relationships (Creech et. al., 2001):

- Information provision

- Nurturing relationships

- Joint action

The community empowerment lead to the highest penetration level of engagement of community members into sustainable development activities, which contributes to the larger number of joint actions and initiatives.

Like education system plays a crucial role in promotion of sustainable development by fostering a sense of individual and collective responsibility, participation in networking and cooperative institutions can also encourage changes in individual behavior.

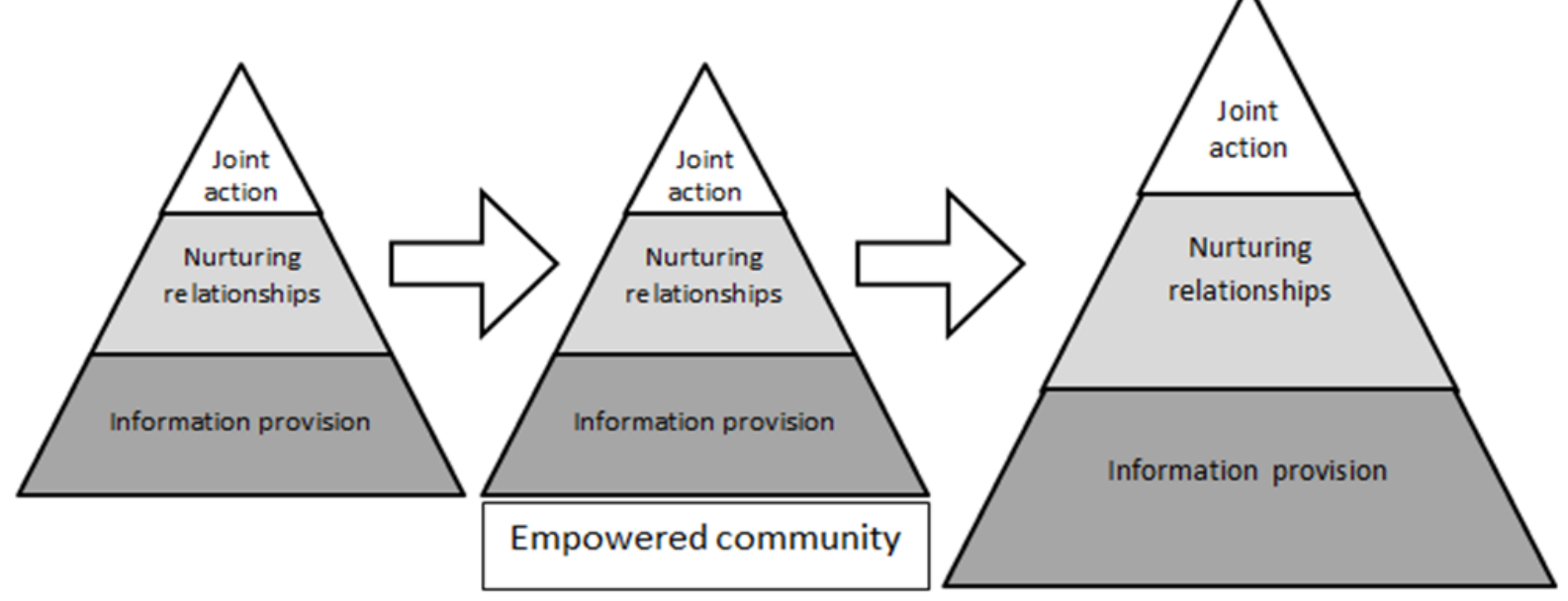

Fig. 1. Role of Community Empowerment in the Engagement Pyramid (modified (Creech et. al., 2001))

Efforts to achieve sustainable development depend on how much the strategy is spread among the society and businesses, and upon the dialogue between the representatives of various society groups.

The term "community" refers both to communities of place and communities of choice or practice, when voluntary group formation leads to the formation of networks. Network formation leads to the creation of group social capital, and under the certain circumstances this leads to the creation of group agency (Newman and Dale, 2007), or the power of empowerment. Networks are powerful means of distributing knowledge, but at the same time they are powerful means of uniting a group of stakeholders for specific purposes. The specific mixture of each group's network ties would contribute to the success of failure of the group to achieve its sustainable development goals. A more diverse group would have more inner resources needed to address the complex nature of sustainable development issues (Newman and Dale, 2007). So, the diversity in networks for sustainable development is crucial for their success. 


\section{Knowledge for the Development}

Knowledge intensive production becomes dominant in the world trade. This is particularly seen in internationally traded financial services, a key knowledge economy activity, as well as software, media and other so called "light GDP" activities (Cooke, 2002). These knowledge economies are highly localized in cities and certain areas, leaving the less developed regions aside. Localized knowledge clusters interact with global value chains managed by multinational corporations. There is now consensus that it exists and is marked by a heightened organizational strength, extensively over the globe and intensively through global value chains. Thus production of goods and services is more deeply integrated for different stages of the value chain in a wider array of global locations than ever before. Global value chains are linked to local value chains, or clusters, as the key mechanism by which globalization works. To put it simple, this means that in knowledge economy, the sustainability issues are becoming everyone's daily issues, having direct impact on the general sustainable development goals.

Besides, clusters are poles of spillover and marketised knowledge through start-ups, new businesses, entrepreneurs and other intermediaries. Credit unions, as will be discussed later, are considered to be one of the most popular financial partners of start-ups and SME, and thus contribute significantly to the knowledge marketization.

In knowledge economy, regional disequilibrium and polarization may be substantially reduced and sustainable development ensured more effectively than in traditional "hard" economies.

Depending on their achieved economic development, all national economies systematically manage the relevant factors of the knowledge economy to ensure that their economies are based increasingly on knowledge, in order to achieve higher rates of economic growth and sustainable development. There is no one universal model of transition to knowledge economy, and the transformations that a particular country should make depend primarily on its achieved current level of economic development (Saundac, 2011.)

However, the transition to the knowledge economy includes four pillars, which are set by the World Bank (Chen et al., 2005):

- $\quad$ educated and skilled workers;

- $\quad$ an effective innovation system of firms, research centers, universities, consultants and other organizations;

- a modern and adequate information infrastructure,

- $\quad$ an economic incentive and institutional regime.

The World Bank (The World Bank info) is calculating several knowledge economy indexes as an indication of overall potential of knowledge development in a given country.

- The Knowledge Economy Index (KEI) takes into account whether the environment is conducive for knowledge to be used effectively for economic development. The KEI is calculated based on the average of the normalized performance scores of a country or region on all 4 pillars related to the knowledge economy - economic incentive and institutional regime, education, innovation and ICT.

- The Knowledge Index (KI) measures a country's ability to generate, adopt and diffuse knowledge. The KI is the simple average of the normalized scores of a country or region on the key variables in three Knowledge Economy pillars education, innovation and ICT.

- The Economic Incentive Regime (EIR) is the simple average of the normalized scores on three key variables: tariff and nontariff barriers, regulatory quality, and rule of law.

- Information and Communication Technology (ICT) is the simple average of the normalized scores on three key variables: telephone, computer, internet penetration.

- The Innovation System (Innovation) is the simple average of the normalized scores on three key variables: total royalty payments and receipts, patent applications, scientific and technical journal articles.

- Education and Human Resources (Education) is the simple average of the normalized scores on three key variables: adult literacy rate, secondary enrollment, tertiary enrollment.

The critics may argue that for the analysis of the impact of financial cooperatives on sustainable development issues, one should analyze correlations between financial cooperative activity and various indicators and indexes of sustainability instead of KEIs.

For measuring the sustainable development, it is common to select and combine a certain pool of indicators for every dimension of sustainable development. There are more than 500 models of sustainable development indicators, where approx. 70 are global, approx. 100 - national, approx. $70-$ regional, and approx. 300 - local (Ciegis, 2011). Taking into account the above, it would be a big challenge to select the proper scope of indicators for a specific valuation, and to calculate the integrated sustainable development index, as all three components (economic, social, environmental) are equally important and neither one of them should not be seen as a priority development area. Sustainable development indexes, inter alia, have a huge strategic and comparative, but little practical information for the decision makers, as the main findings lay behind the sustainable development indicators, which constitute the indexes. There are open initiatives for local indexes, which could be analyzed in the context of this research, e.g. the Sustainable Communities Index (SCI) - a system of indicators for livable, equitable and prosperous cities. The SCI includes over 100 measures that can be used to track diverse sustainability objectives for the environment, transportation systems, community cohesion and civic engagement, public facilities, education, housing, and economic strength, and health systems (Sustainable 
Communities Index). However, most of such indexes are just open initiatives, lacking methodology base and positive track record.

For example, the certain Sustainable Development Indicators (SDIs) are used to monitor the EU Sustainable Development Strategy. More than 130 indicators are grouped into the following 10 themes $(33,34)$ :

- $\quad$ Socio-economic development (headline indicator (HI) - real GDP per capita)

- Sustainable consumption and production (HI resource productivity)

- Social inclusion (HI - risk of poverty or social exclusion)

- Demographic changes (HI - employment rate of older workers)

- $\quad$ Public health (HI - life expectancy and healthy life years)

- Climate change and energy (HI - greenhouse gas emissions, consumption of renewables)

- Sustainable transport (HI - energy consumption of transport relative to GDP)

- Natural resources (HI - abundance of common birds, conservation of fish stocks)

- Global partnership (HI - official development assistance)

- Good governance (no HI)

However, the aggregate index of sustainable development in the EU is not calculated, and the regional comparison is possible only on indicator level.

The Environmental Performance Index (EPI) centers on two broad environmental protection objectives (The Environmental Performance Index):

- Environmental health, i.e. reducing environmental stresses on human health, and

- Ecosystem vitality, i.e. promoting ecosystem vitality and sound natural resource management.

- The Ecosystem Vitality Index (EVI) encompasses the following indicators (The Environmental Performance Index):

- air pollution (ecosystem effects),

- water resources (ecosystem effects),

- biodiversity and habitat,

- forestry,

- fisheries,

- agriculture,

- climate change.

The authors of this paper will select and analyze the correlation of those indexes with the certain statistical activity rates of financial cooperatives.

\section{Community Empowerment}

Rio +20 has once again noted, that people's opportunities to influence their lives and future, participate in decision making and voice their concerns are fundamental for sustainable development (The Future We Want, 2012).

Consumers today are looking for a relationship, not just a transaction; they want to be and are active participants in almost all value chain of most products. The same principles are valid for the social processes. Engagement is a process of relationshipbuilding that acknowledges the power of two-way communications. It is a process of moving people from being recipients of information to being partners in the process of developing new solutions. (Creech et. al., 2001). Community participation can extend democracy, citizenship and accountability; participatory initiatives can inspire sustainable action on poverty and social inclusion (Warburton, 1998). Ensuring that local people are able to participate in the decisions and activities which affect their living environment, implement the traditional ideological aspect of sustainable development, i.e. meeting our own needs without compromising the ability of future generations to meet their needs. When talking about the community actions, the engagement process is strongly related with the empowerment action and state.

Empowerment is a construct that links individual strengths and competencies, natural helping systems, and proactive behaviors to social policy and social change. Empowerment theory, research, and intervention link individual well-being with the larger social and political environment (Perkins et al., 1995). Empowerment theory provides principles and a framework for organizing one's knowledge. A theory of empowerment suggests ways to measure the construct in different contexts, to study empowering processes (Zimmerman et al., 2000).

Community empowerment networks and organizations use various methods to help and assist communities to satisfy their needs and promote and develop various initiatives. It should be noted that the best known and usually world-wide networks and initiatives are mostly related to the primary issues of sustainable development, i.e. social and discrimination issues, life quality, environmental protection, democracy.

However, there is plenty of other, smaller scale and local community empowerment cases around us. The most important thing about such local community empowerment cases is that they enable more people to play active role in the decisions that affect their communities (International Association for Community development).

An empowered community has 5 community empowerment dimensions (Community empowerment...):

- confident - working in a way which increases peoples skills, knowledge and confidence - and instills a belief that they can make a difference;

- inclusive - working in a way which recognizes that discrimination exists, promotes equality of opportunity and good relations between groups and challenges inequality and exclusion;

- organized - working in a way which brings people together around common issues and concerns in organizations and groups that are open, democratic and accountable;

- co-operative - working a way which builds positive relationships across groups, identifies 
common messages, develops and maintains links to national bodies and promotes partnership working;
- influential - working in a way which encourages and equips communities to take part and influence decisions, services and activities.

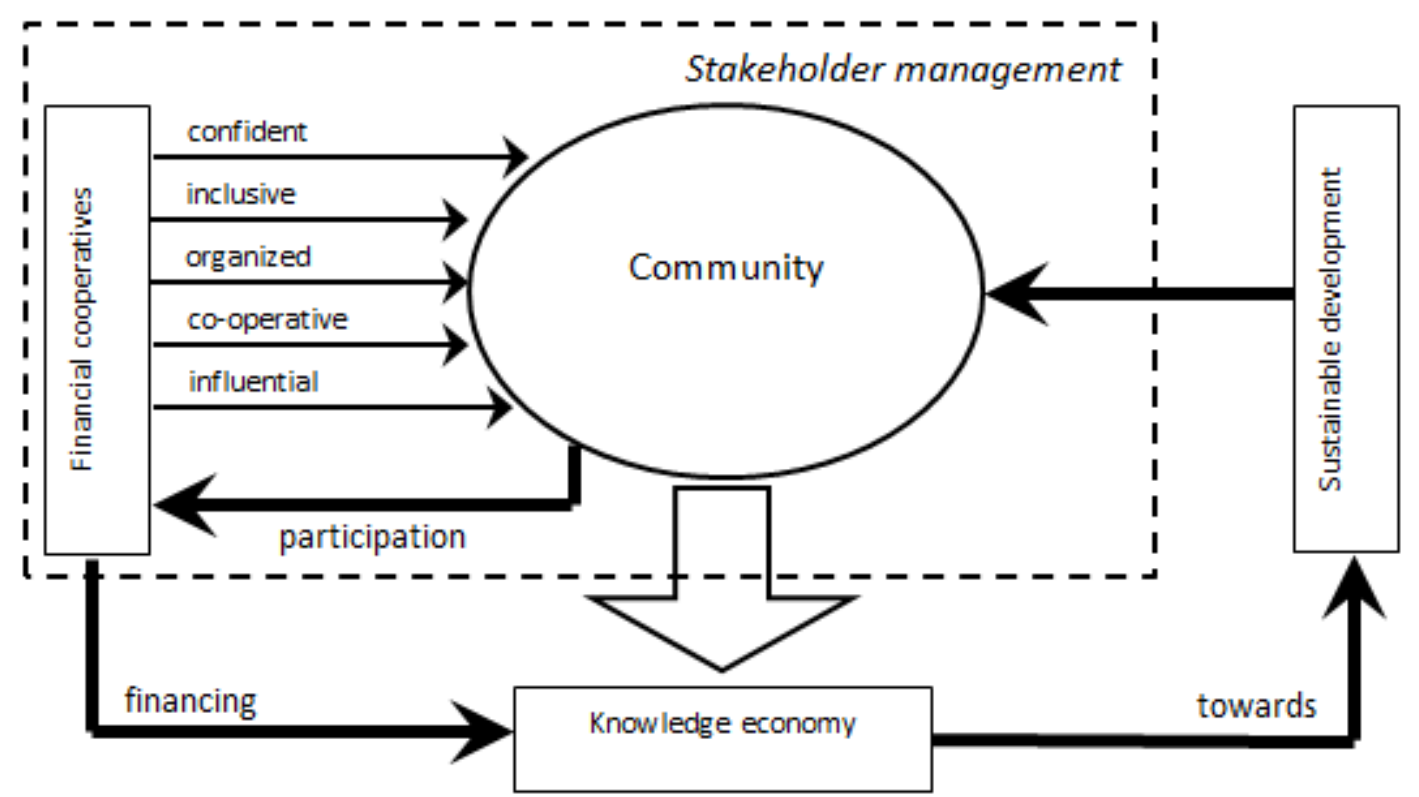

Fig. 2. Financial Cooperatives as Drivers for Sustainable Development in the Knowledge Economy

Based on their previous researches $(9,10,11$, $12,13)$, the authors of this paper consider the financial institutions as strong and substantial stakeholders in sustainable development and knowledge economy development processes.

Additionally, the recent researches show that the diversity of ownership types and business models in banking is particularly important for a sound and reliable financial system. A financial system that presents a diversified institutional structure, including institutional types, will be more efficient in promoting economic growth and reducing poverty (Groeneveld, 2001). The crisis of 2007-2009 has shown the added value of the cooperative banking model. Cooperative banks are stakeholder-value institutions, when the traditional commercial institutions are referred to as shareholder-value ones. However, it should be noted that the contribution of cooperative banks to banking market structures is only noticeable if the cooperative banking model enjoys a critical mass.

\section{Financial Cooperatives}

Cooperatives exist to serve their members, whether they are the customers, employees or the local community. These members are the owners, with an equal say in what the cooperative does. As well as getting the products and services they need, members help shape the decisions their cooperative makes. 100 million people around the world are employed by cooperatives, 800 million are members. Cooperative enterprises also fit with the EU2020 strategy that aims for "a sustainable economy, putting people and responsibility first with a sustained fight against exclusion and a transition to a green economy" (Cooperatives Europe).

Certain major principles define cooperatives and their specific corporate governance features. The International Cooperative Alliance has prepared a list of principles upon which cooperatives rely worldwide in order to conduct their operations. While certain specific regional principles are found throughout the world, seven major principles are predominant. More specifically, cooperatives are marked by the following (Boned):

- open and voluntary membership,

- democratic management by members,

- economic involvement of members,

- autonomy and independence vis-à-vis any external power,

- training and information duties,

- tendency to cooperate with other cooperatives and involvement in community life.

The existence of members is one of the major differences between cooperatives and any other type of enterprises. Members of cooperatives are their stakeholders at different levels. The most specific attribute of cooperatives is their corporate governance. Corporate governance that is based on participation of stakeholders of different social groups and competencies, and on meeting the interest of such different stakeholders, needs to be analyzed in the context of modern management theories.

The role of financial sector in fostering sustainable development is not a new phenomenon. Sustainable banking, alternative banking, green banking, ethical banking and similar concepts are widely accepted and employed in sector of financial services and crediting. The role of financial institutions in contributing towards the sustainable 
development is particularly significant due to their intermediary role in the economy. Being influenced by stakeholders and being stakeholders themselves, modern financial institutions are looking for new methods of activity, systematically and holistically encompassing various spheres of management activity, adopting sustainable and alternative (i.e. different from traditional) banking principles.

In the current context of globalization, financial institutions play key roles in channeling financial flows, creating financial markets and influencing international policies. Usually the bank has more possibilities than other market players to evaluate risk and creditability of the clients, and this attribute is of a high significance striving for sustainability. From profitability point of view it is rather difficult to convince banks to commit to principles of sustainable development, therefore a significant role of direct and indirect pressure from stakeholders is becoming indispensable (Cepinskis et al., 2006). Sustainable oriented bank is able to react to stakeholders' pressure faster than not sustainable oriented. Faster reaction is a precondition to gain some competitive advantage not only because of successful solving of problems but also on playing of possibilities. The more bank responses to sustainable development issues, the better possibilities of faster reaction and competitive advantage are gained.

Different studies show that due to their "one member - one vote" corporate management system, cooperative banks may develop a more sustainable lending models, have the ability to develop more socially oriented business, their legal statutory mandate, their ethical codes and the stakeholder oriented governance produce positive effect on economic development, economic growth, reducing financial exclusion, improving the value of entrepreneurial human capital with long run banking relationships and horizons, cooperative banks become active part of economic change. Moreover cooperative banks produce financial sustainability, and the ability of cooperative banks to produce financial stability is showed both theoretically and empirically (Leogrande, 2010).

Despite their stakeholder oriented governance, cooperative banks are still banks - most often large, vertical and slow organizations, and their communication with communities is often of a "presenting the annual social accountability report" manner. However, the active role of members in the decision making processes, their direct influence at the local level, and immediate social or/and economic affect to the local community makes the issue specific.

The study on credit union impact on rural development in Canada proved the decreasing statistical correlation between the size of the credit union and its participation in rural development processes. This conclusion is particularly important as it shows that the size of financial institution (which is directly related to larger assets, larger loans and stronger credit granting possibilities) does not necessary coincide with the involvement in sustainable development schemes. (Mavenga, 2010)

The authors of this paper have indicated the credit unions - small cooperative financial institutions - as possible change actors for the direct empowerment of local communities.

\section{Credit Unions}

Credit unions are self-help cooperative financial organizations geared to attaining the economic and social goals of members and wider local communities. Each credit union is governed by its members. Credit unions cannot do business with the general public due to charter limitations based on serving a membership that is characterized by a common bond. The common bond is based on a pre-existing social connection (such as belonging to a particular community, industrial or geographic group) (Report of the Commission on Credit Unions). In the past, this helped in the absence of more formal control and management systems of credit unions. However, the recent tendencies in credit union movement show that the common bond also limits commercial diversification, and in many jurisdictions has become less important as the movement has matured.

In 2012, there were 55.952 credit unions operating in 101 countries. These credit unions had a membership of over 200 million, which equates to a population penetration of $7,72 \%$ and had total assets under their control of approximately \$1.694 billion, savings of USD 1.293 billion, loans of USD 1.083 billion and reserves of USD 162 billion (World Council of Credit Unions). The aforementioned indicators will be analyzed by the authors of this paper in order to establish possible correlations between the knowledge economy development indexes and the credit union development stage.

An organizational life-cycle theory assumes that credit unions pass the following stages of development: nascent, transition and mature. This typology contains an assumption concerning "economic determinism" in so far as the asset size of credit unions is seen as a major determinant of credit union behavior (Ferguson, 1997). Though with a certain limitations, the typology provides a sufficient framework to assess the credit union movement within each country (Table 2). Nascent industries can be found primarily in the developing countries where they are often seen as vehicles for reducing poverty within more general microfinance programs.

Most credit unions are somewhere in the transition stage, and few industries can be ascribed to the mature phase (i.e. USA, Canada, Australia, France, Korea).

In 2002, the typology was updated to include a postmature phase (Ferguson, 1997). The post-mature phase is supposed to be the final stage in the life cycle development of a credit union. At this stage the credit union and the industry supporting the credit union is of sufficient standard to allow the credit union to convert (to transform) into commercial financial 
institution (mostly - a commercial bank). The identification of this phase was mainly determined by a specific case in Canada, where one particular credit union was successfully reorganized to a commercial bank.

Table 2. Stages and Attributes of Credit Unions Maturity (Ferguson, 1997)

\begin{tabular}{||l|l||}
\hline Stage of industry & Attributes \\
\hline Nascent Industry & Small Asset Size \\
& Highly Regulated \\
& Tight Common Bond \\
& Strong Emphasis on Voluntarism \\
& Serve Weak Sections of Society \\
& Single Savings and Loans Product \\
& Requires Sponsorship from wider Credit Union Movement to take root \\
& High Commitment to Traditional Self-Help Ideals \\
\hline Transition Industry & Large Asset Size \\
& Shifts in Regulatory Framework \\
& Adjustments to Common Bond \\
& Shifts towards greater Product Diversification \\
& Emphasis on Growth and Efficiency \\
& Weakening of Reliance on Voluntarism \\
& Recognition of need for Greater Effectiveness and Professionalism of Trade Bodies \\
& Development of Central Services \\
\hline Mature Industry & Large Asset Size \\
& Deregulation \\
& Loose Common Bond \\
& Competitive Environment \\
& Electronic Technology Environment \\
& Well Organized, Progressive Trade Organizations \\
& Professionalization of Management \\
& Well Developed Central Services \\
& Diversification of Products and Services \\
& Products and Services Based on Market Rate Structures \\
& Emphasis upon Economic Viability and Long Term Sustainability of a Credit Union \\
& Rigorous Financial Management of Operations \\
& Deposit Insurance Mechanism Established \\
\hline
\end{tabular}

Credit unions are committed to building sustainable communities by following these principles (A roadmap for the development of a sustainability, 2010):

- Demonstrating co-operative and sustainable governance. As co-operatives, credit unions are leaders in democratic governance, accountable to members and broader society.

- Promoting social inclusion and diversity. Led and directed by their community-based membership, credit unions are uniquely responsive to emerging social change and needs

- Fostering economic development. Credit unions are dependable partners in promoting the economic growth and prosperity of the communities they serve. Credit unions lead the industry in providing loans based on character and foster economic development in a variety of ways, helping small businesses and new entrepreneurs flourish. Other examples of credit union economic development include partnerships with other cooperatives and community organizations to build community housing, and development of unique microfinance programs to address local needs

- Encouraging environmental sustainability. Each credit union has its own perspective on how to apply this principle. For some credit unions, this involves contributing to environmental organizations and efforts. Many have adopted or are developing innovative approaches and services that reduce the ecological footprints of their members and make their own business operations less wasteful and more cost-efficient

Credit unions exist to attain the economic and social goals of their members, and not maximizing profit and shareholder wealth. This enables credit unions to empower communities to pursue specific interests of the communities. Credit unions cannot be sustainable, unless their communities are sustainable, thus to promote and strengthen credit unions is an effective instrument for sustainable development.

Currently there are 75 credit unions in Lithuania, and the Lithuanian credit union sector experiences fundamental changes in credit union regulation, initiated by the Central Bank of Lithuania.

Lithuanian credit unions have to follow the standards that are applied to the banking sector, or even more strict standards. Under the recent regulations, Lithuanian credit unions have to maintain higher operating standards that, in some cases, do not help credit unions to compete in the banking market with the commercial banks (Kaupelyte and McCarthy, 2006). Some authors presume that the regulation of Lithuanian credit union activities is stricter than it should be for their stage of development (e.g. in comparison with the regulation of Irish credit unions to date). Strict regulation influences the development 
of credit unions in Lithuania, however the regulatory regime is not always aligned with the stage of credit union development and may, indeed, reflect the economic policy of the country and, more further, influence the sustainable development issues.

For the research, 62 credit unions were selected (members of the Central credit union, which data was available).

These credit unions had a membership of over 124 thousand (penetration of $5 \%$ ), assets under their control of approximately USD 537 million, savings of USD 454 million, loans of USD 308 million (World Council of Credit Unions). Credit unions in Lithuania are supposed to be in the $2^{\text {nd }}$ development stage. The EVI of Lithuania is 57,88 (number 27 of total 132 states).

\section{Correlations Between Prevalence of Credit Unions and Sustainable Development}

The authors of this paper have made a preliminary analysis of statistical data in order to establish whether there is a correlation between the level of prevalence of credit unions in different countries and the level of development of the knowledge economy and the selected sustainable development indicators.

The data of unions (number of credit unions, amount of savings, loans, assets and level of penetration) all over the world has been grouped (World Council of Credit Unions) and maturity levels of credit unions in every country have been determined according to Ferguson Ch. and McKillop D.G (Ferguson, 1997).

The data of KEI, KI, EIR, Innovation, Education and ICT has been grouped (The World Bank info). The research scope has included 78 countries.

The Ecosystem Vitality index (EVI) calculated by Yale University, has been selected and grouped (The Environmental Performance Index). The research scope has included 64 countries. Different number of countries was determined by the limited statistical data.

Main findings are represented in tables $(3-8)$ below.Correlation of credit union number with KEI, $\mathrm{KI}$ and EIR is not established in any maturity level.

Table 3. Correlations With Number of Credit Unions

\begin{tabular}{||l|l|l|l||}
\hline & 1 -st maturity level & $2-n d$ maturity level & $3-$ rd maturity level \\
\hline KEI & $-0,214$ & $-0,224$ & 0,135 \\
\hline KI & $-0,234$ & $-0,218$ & 0,247 \\
\hline EIR & $-0,095$ & $-0,184$ & 0,088 \\
\hline Innovation & $-0,240$ & $-0,072$ & 0,716 \\
\hline Education & $-0,181$ & $-0,298$ & $-0,515$ \\
\hline ICT & $-0,259$ & $-0,218$ & 0,750 \\
\hline EVI & 0,184 & 0,184 & 0,492 \\
\hline
\end{tabular}

Strong direct correlation between the number of the 3rd maturity level credit unions and Innovations and ITC is established. This can be probably explained by the economy structure of the 3rd maturity level countries, where the knowledge intense (Innovations) and technology oriented (ITC) sectors prevail the agricultural and traditional industrial sectors.

The inverse correlation between the 3rd maturity level and Education and EVI is established. A more detailed study should be carried out in order to explain and find out more arguments for this particulary unexpected correlation. However, the assumption can be made that countries with the 3rd maturity level cooperatives are already saturated and accept the need for education and preservation of eco system as a natural state of being and a matter of everyone (including state policy). While the countries of a lower maturity level still more deeply correlated the possibility for education with the credit posibilities for the individuals.

Table 4. Correlations With Number Of Credit Unions Members

\begin{tabular}{||l|l|l|l||}
\hline & $1-$ st maturity level & $2-n d$ maturity level & $3-$ rd maturity level \\
\hline KEI & $-0,073$ & $-0,200$ & 0,221 \\
\hline KI & $-0,097$ & $-0,167$ & 0,322 \\
\hline EIR & $-0,128$ & $-0,216$ & 0,165 \\
\hline Innovation & 0,027 & $-0,026$ & 0,746 \\
\hline Education & $-0,128$ & $-0,174$ & $-0,486$ \\
\hline ICT & $-0,151$ & $-0,208$ & 0,808 \\
\hline EVI & $-0,120$ & 0,188 & 0,468 \\
\hline
\end{tabular}

There is no significant correlation of number of credit unions members neither with KEI, KI, EIR nor Education in any maturity level.

The significant correlation is established between the number of credit union members of the $3^{\text {rd }}$ maturity level and Innovation and ICT. This is a particularly important correlation, as it tells us about the correlations between the higher participation of individuals in cooperative and community activities, with the level of innovation activities. However, the implication can be made that these individuals participate in financial cooperatives not just because of the scarcity of financial resources for the basic 
needs, but they see the cooperative as a fund for their activities related with more knowledge intense needs.

Table 5. Correlations With Savings

\begin{tabular}{||l|l|l|l||}
\hline \hline KEI & $1-$ st maturity level & $2-n d$ maturity level & $3-r d$ maturity level \\
\hline KI & $-0,029$ & $-0,063$ & 0,271 \\
\hline EIR & $-0,043$ & $-0,025$ & 0,354 \\
\hline Innovation & 0,019 & $-0,120$ & 0,214 \\
\hline Education & 0,077 & 0,058 & 0,769 \\
\hline ICT & $-0,080$ & $-0,067$ & $-0,481$ \\
\hline EVI & $-0,094$ & $-0,024$ & 0,835 \\
\hline
\end{tabular}

There is no significant correlation of savings neither with KEI, KI, EIR nor Education in any maturity level.

The significant correlation is established between the savings in credit unions of the $3^{\text {rd }}$ maturity level and Innovation, ICT and EVI. Taking into account the sustainability aspect between the various spheres of activity, this implies for a higher level of sustainable development in the more matured industries, as they are able to accumulate savings, at the same time to invest into knowledge intense activities, and at the same time to participate in ecosystem vitality projects. The previous correlations justify this one, as the more members participate in cooperative activities, the broader scope of sustainable development issues can be obtained.

Table 6. Correlations With Loans

\begin{tabular}{||l|l|l|l||}
\hline \hline KEI & 1-st maturity level & $2-n d$ maturity level & $3-r d$ maturity level \\
\hline KI & $-0,033$ & $-0,041$ & 0,414 \\
\hline EIR & $-0,046$ & $-0,016$ & 0,296 \\
\hline Innovation & 0,015 & $-0,070$ & 0,399 \\
\hline Education & 0,075 & 0,079 & 0,902 \\
\hline ICT & $-0,080$ & $-0,062$ & $-0,618$ \\
\hline EVI & $-0,099$ & $-0,026$ & 0,839 \\
\hline
\end{tabular}

There is no significant correlation of granted loans neither with KEI, KI nor EIR in any maturity level.

The significant correlation is established between the granted loans by the credit unions of the 3rd maturity level and Innovation, ICT and EVI.

The inverse correlation between the granted loans by the 3rd maturity level and Education is

Table 7. Correlations With Assets

\begin{tabular}{||l|l|l|l||}
\hline & 1-st maturity level & $2-n d$ maturity level & $3-$ rd maturity level \\
\hline KEI & $-0,068$ & 0,026 & 0,345 \\
\hline KI & $-0,088$ & 0,048 & 0,311 \\
\hline EIR & 0,003 & $-0,006$ & 0,314 \\
\hline Innovation & 0,048 & 0,139 & 0,850 \\
\hline Education & $-0,129$ & 0,011 & $-0,572$ \\
\hline ICT & $-0,141$ & 0,022 & 0,836 \\
\hline EVI & $-0,158$ & 0,054 & 0,584 \\
\hline
\end{tabular}

The inverse correlation between the asstes of the 3rd maturity level unions and Innovations and Education is established. This approves the already discussed previous correlation (Table 3), showing that the countries of a lower maturity level still more deeply correlated the possibility for education with the credit posibilities for the individuals.

One of the key indicators of the impact of credit unions on social trends - participation in credit union activities (penetration) rate, which is measured by calculating the percentage of the working-age population having membership with the credit union in other words, what part of the community, whose established. There is no significant correlation of assets neither with KEI, KI nor EIR in any maturity level.

The significant direct correlation between the assets of the 3rd maturity level and Innovation and ICT is established

interests may be empowered by the credit union, is involved in the credit union activities.

There is no correlation established between the penetration of the $1^{\text {st }}$ and the $2^{\text {nd }}$ maturity level unions with any of the six analyzed KE indicators.

There is no correlation established between the $\mathrm{KI}$ and penetration in any maturity levels. However, the strong direct correlation is established between the penetration of the $3^{\text {rd }}$ maturity level unions and KEI, EIR, innovation and ICT, the strongest correlation with EVI, and the inverse correlation with Education. 
Table 8. Correlations With Penetration Level

\begin{tabular}{||l|l|l|l||}
\hline \hline KEI & 1 -st maturity level & $2-n d$ maturity level & $3-$ rd maturity level \\
\hline KI & $-0,190$ & 0,183 & 0,852 \\
\hline EIR & $-0,260$ & 0,244 & 0,338 \\
\hline Innovation & 0,062 & 0,029 & 0,897 \\
\hline Education & $-0,192$ & 0,225 & 0,937 \\
\hline ICT & $-0,310$ & 0,228 & $-0,556$ \\
\hline EVI & $-0,230$ & 0,274 & 0,735 \\
\hline
\end{tabular}

As was already discussed before, a more detailed study should be carried out in order to explain and find out more arguments for this particulary unexpected correlation with Education. Also the future challenge for the researches is to develop a comprehensive model for the successful empowerment communities of credit unions in creating and developing sustainable knowledge economy.

\section{Conclusions}

The Rio+20 conference adopted the outcome document "The Future We Want" which highlights the current issues of sustainable development. Among the other insights, the Rio+20 pays the particular importance on engaging major groups and other stakeholders into sustainable development processes. The best route to global sustainable development may be through accelerated technology development, business innovation and structural change, leading to sustainable knowledge economy.

Knowledge intensive production becomes dominant in the world trade. In knowledge economy, regional disequilibrium and polarization may be substantially reduced and sustainable development ensured more effectively than in traditional "hard" economies. Knowledge economies are highly localized in cities and certain areas, leaving the less developed regions aside.

The localized knowledge clusters interact with global value chains, and production of goods and services is more deeply integrated for different stages of the value chain in a wider array of global locations than ever before. Global value chains are linked to local value chains, or clusters, as the key mechanism by which globalization works. To put it simple, this means that in knowledge economy, the sustainability issues are becoming everyone's daily issues, having direct impact on the general sustainable development goals.

Clusters are poles of spillover and marketised knowledge through start-ups, new businesses, entrepreneurs and other intermediaries, and small financial cooperatives are considered to be one of the most popular financial partners of start-ups and SME, and thus contribute significantly to the knowledge marketization.

Depending on their achieved economic development, all national economies manage the relevant factors of the knowledge economy to ensure that their economies are based increasingly on knowledge, in order to achieve higher rates of economic growth and sustainable development.

The recent studies on management and community research indicate for the increased weight of stakeholder management and related community empowerment mechanisms.

Community empowerment networks and organizations use various methods to help and assist communities to satisfy their needs and promote and develop various initiatives for sustainable development. The most important thing about local community empowerment cases is that they enable more people to play active stakeholder role in the decisions that affect their communities.

Financial institutions are strong and substantial stakeholders in sustainable development and knowledge economy development processes. The recent researches show that the diversity of ownership types and business models in banking is particularly important for a sound and reliable financial system.

Cooperative banks are stakeholder-value institutions, when the traditional commercial institutions are referred to as shareholder-value ones. The existence of members is one of the major differences between cooperatives and any other type of enterprises. Members of cooperatives are their stakeholders at different levels. Small financial cooperatives, like credit unions exist to attain the economic and social goals of their members, and not maximizing profit and shareholder wealth. This enables credit unions to empower communities to pursue specific interests of their local communities.

Credit unions of the $1^{\text {st }}$ and the $2^{\text {nd }}$ maturity level are not KE drivers, there are no reliable correlations with KEI, KI, EIR, Innovation, Education, ICT and EVI. It may be assumed that unions of the first maturity levels do not empower communities for the development of knowledge society and knowledge economy.

Credit unions of the $3^{\text {rd }}$ maturity level become an evident drivers for knowledge economy, as the direct correlation between the different characteristics of the credit unions of the $3^{\text {rd }}$ maturity level with Innovation, ICT and EVI are established. The most significant is the correlation between the penetration level and EVI.

The nonexistence of correlation between the $3^{\text {rd }}$ maturity level and KI justifies the analysis, as the difference between the KEI and KI is mainly the institutional aspect and indicators, i..e. the economic incentive and economical regime, which is the 
indicative description of the activity of the financial cooperatives.

The analysis indicates for an increasing positive correlation depending on credit union industry development stage. The future challenge for the researches is to develop a comprehensive model for the successful empowerment communities of credit unions in creating and developing sustainable knowledge economy.

\section{References}

Sundac, D., Fatur Krmpotic, I. Knowledge Economy Factors and the Development of Knowledge-based Economy. Croatian Economic Survey Vol. 13 No.1 2011.

Chen, D. H. C., Dahlman, J. The Knowledge Economy, the KAM Methodology and World Bank Operations,

The World Bank, 2005,

http://siteresources.worldbank.org/KFDLP/Resources/ KAM_Paper_WP.pdf.

The World Bank. http://info.worldbank.org

Zirgutis, V. Organization management assessing stakeholder influence. Doctoral Dissertation, Vytautas Magnus University, Kaunas, 2008.

Perkins D.D., Zimmerman M. A. Empowerment Theory, Research, and Application. American Journal of Community Psychology, Vol. 23, No.5, 1995 http://dx.doi.org/10.1007/BF02506982

Zimmerman M. A. Empowerment Theory: Psychological, Organizational and Community Levels of Analysis. Handbook of Community Psychology, ed. By Julian Rappaport and Edward Seidman. Kluwer Academic/Plenum Publishers, New York, 2000

International Association for Community Development. That is community empowerment. http://www.iacdglobal.org

Community empowerment: An introduction to community empowernment. http://changesuk.net/

Cepinskis J., Zirgutienè S., Zirgutis V. The Role of Financial Institutions Solving Contradictions of Sustainable Development. // Environmental Research, Engineering and Management No. 3 (37). - Kaunas: Technologija, 2006. ISSN 1392-1649.

Ivaskeviciute, L., Macerinskienc, I., Vidauskaite, S. Economic and Environmental Sustainability in Loan Portfolio Management of Commercial Bank // New Trends of the Development of Industry, November 26-27, 2003, Brno. - Brno: Brno University of Technology. ISBN 80214-2518-0

Ivaskeviciute, L., Macerinskiene, I., Vidauskaite, S. Zirgutis, V. Bank Risk Management in the Context of New Trends of Banking Development // New Trends of the Development of Industry, November 26-27, 2003, Brno. Brno: Brno University of Technology. ISBN 80-214-2518-0

Vidauskaite S., Zirgutis V. Sustainability Reporting by Financial Institutions // Moderne Pristupy k Manažmentu Podniku (Modern Approaches to Management): International Scientific Conference, 13-14 May 2004, Bratislava, Slovenska republika. - Bratislava, 2004, ISBN 80-969189-0-7

Zirgutiene, S. Compliance risk in sustainable bank management // Haridus ja Majandus $2005=$ Education and economy 2005: rahvusvahelise teaduskonverentsi materjalid $=$ the materials of international scientific conference, 5 mai 2005, Tallinn / Tallinn university of technology, Educational research centre, Tallinn college. ISBN 9985-894-85-5. - Tallin, 2005.

Groeneveld, $\mathrm{H}$. The Cooperative Banking Model: Performance and Opportunities. 2011

Cooperatives Europe.

http://www.coopseurope.coop/about-cooperatives

Boned, O. Members of cooperatives in corporate governance: How should European cooperative banks cooperate? ICBA Europe

Leogrande, A. Cooperative banks vs financial crisis: an application of the STV vs. SHV debate. 2010 2012

Report of the Commission on Credit Unions, Dublin,

World Council of Credit Unions. www.woccu.org

Ferguson Ch., McKillop D.G. An Industry Approach to Classifying Credit Union Development, 1997

Ward, A.M, McKillop, D. Recognising Credit Union Industry Progression. 2002

Johnston, P. Sustainability and Jobs in the Knowledge Economy. Journal of Universal Computer Science, vol. 7, no.6 (2001). http://www.jucs.org/

Creech, H., Willard, T. Startegic intentions: Making knowledge networks for sustainable development. International Institute for (21) Sustainable Development. 2001. ISBN 1-895536-48-0

Ciegis, R., Ramanauskiene, J. Integruotas darnaus vystymosi vertinimas: Lietuvos atvejis. Management theory and studies for rural business and infrastructure development. 2011. Nr. 2 (26). Research papers. ISSN 1822-6760.

Warburton, D. Community and sustainable development: participation in the future. 1998. ISBN 185383-531-5

Credit Unions Build Sustainable Communities. Credit Union Central of Canada, http://www.cucentral.ca

Staniskis, J.K. Rio+20: Towards the Green Economy and Better Governance (Editorial). Environmental research, engineering and management, Vol 59, No 1 (2012). Online ISSN: 2029-2139

Cooke, Ph., De Marchi, B. Generative Growth, Knowledge Economies and Sustainable Development: Implications for Regional Foresight Policy. European Commission, 2002. http://ec.europa.eu/research/socialsciences/pdf/generative-growth-knowledge-

economies_en.pdf

A roadmap for the development of a sustainability strategy. Credit Union Central of Canada, 2010.

Mavenga, Fortunate. Economic impact of credit unions on rural communities (Master's thesis). University of Saskatchewan, Saskatoon, SK. 2010.

Sustainable Communities Index.

http://www.sustainablecommunitiesindex.org/

Newman, L., Dale, A. Homophily and agency: creating effective sustainable development networks. Environment, Development and Sustainability. 2007/9.

Eurostat. http://epp.eurostat.ec.europa.eu

Sustainable development in the European Union: 2011 monitoring report of the EU sustainable development strategy. http://epp.eurostat.ec.europa.eu

The Future We Want: Outcome document adopted at Rio+20. Report of the United Nations Conference on Sustainable develppment. Rio de Janeiro, Brazil, 20-22 June 2012. United Nations, N.Y. 2012. http://www.uncsd2012.org

Post-2015: framing a new approach to sustainable development. Post-2015 Sustainable Development Agenda. IRF2015. http://sustainabledevelopment.un.org/

$\operatorname{COM}(2013) 92$. A decent life for all: ending poverty and giving the world a sustainable future. 
http://ec.europa.eu/environment/international_issues/pdf/rio /COM\%282013\%2992\%201_EN_ACT_part1_v8.pdf

The Environmental Performance Index/ http://sedac.ciesin.columbia.edu

Kaupelyte, D., McCarthy, O. Risk Management in Lithuanian and Irish Credit Unions: Trends and Impacts on Credit Union Development. Journal of Rural Cooperation, 34(2), 2006:179-196.

Prof., habil dr. Jonas ČEPINSKIS - Vytautas Magnus University, Department of Economics and Management

Main research area: environmental management, sustainable development, alternative banking

Address: S. Daukanto g. 28, Kaunas

Tel.: $\quad+37037327856$

E-mail: $\quad$ jonas.cepinskis@evf.vdu.lt
Dr. Vytautas ŽIRGUTIS - Vytautas Magnus University, Department of Economics and Management

Main research area: stakeholder management, strategic management, management systems

Address: S. Daukanto g. 28, Kaunas

Tel: $\quad+37061244900$

E-mail: $\quad$ vytautas.zirgutis@evf.vdu.lt

Sandra ŽIRGUTIENÉ - UAB Finansų valdymo sprendimų centras, CEO

Main research area: sustainable development, sustainable banking, sustainability

Address: A. Vivulskio g. 7, Vilnius

Tel.: $\quad+37068794656$

E-mail: $\quad$ s.zirgutiene@gmail.com

\title{
Finansų kooperatyvai kaip darnaus vystymosi varomosios jègos žinių ekonomikoje
}

\author{
J. Čepinskis ${ }^{1}$, V. Žirgutis ${ }^{1}$, S. Žirgutiené ${ }^{2}$ \\ ${ }^{1}$ Ekonomikos ir vadybos fakultetas, Vytauto Didžiojo universitetas, Lietuva \\ ${ }^{2}$ UAB Finansu valdymo sprendimu centras, Lietuva
}

(gauta 2013 m. spalio mèn.; atiduota spaudai 2013 m. gruodžio mén.)

Darnus vystymasis žinių ekonomikoje susiduria su naujais iššūkiais. Darnus vystymasis turi savo įtakos grupes ir savo varančiąsias jègas, kurių reikšmė skiriasi. Finansiniai kooperatyvai iš pirmo žvilgsnio neatrodo reikšminga darnaus vystymosi varančioji jèga, tačiau, atidžiau panagrinejjus finansų kooperatyvų įtaką vykstantiems ekonominiams, aplinkosaugos ir socialiniams procesams, galima daryti prielaida, kad jų vaidmuo yra kur kas svarbesnis. Šiame straipsnyje analizuojama finansų kooperatyvų itaka darniam vystymuisi žinių ekonomikos kontekste igalinant bendruomenes. Kadangi finansų kooperatyvai per narius yra susiję su bendruomenemis, jų priimami sprendimai dè projektų finansavimo gali labiau atitikti bendruomenès interesus nei komercinès paskirties bankų sprendimai. Atliekant koreliacinus skaičiavimus, buvo siekiama išsiaiškinti, kokią itaką finansiniai kooperatyvai turi darniam vystymuisi žinių ekonomikoje. 